\title{
Ansambel Musik Nggo Lamba Dalam Upacara Pati Ka Du'a Bapu Ata Mata Di Danau Kelimutu Ende Flores Nusa Tenggara Timur
}

\author{
Ariesty Victoria Kartina ${ }^{1}$
}

\begin{abstract}
Performance of art in a community is a part from community culture it self. Community as the owner of culture has a role to preserve it. Performance of art has different shape from each other. Performance of art it self has a special meaning and this is corresponding with it's context. Nggo Lamba music performancein Lio Ende Flores East Nusa Tenggara is a folk performing arts that's used to accompany custom dance at many kinds of custom ceremony like thanksgiving ceremony, wedding ceremony, Pati Ka ceremonyand etc. This writing is a discription of the series process of a Pati $\mathrm{Ka}$ ceremonies at Kelimutu lake from preparing until peak of the event ceremonies.
\end{abstract}

Keywords: Nggo Lamba, Pati Ka Du'a Bapu Ata Mata.

\begin{abstract}
Abstrak
Pertunjukan seni dalam sebuah komunitas merupakan bagian dari budaya masyarakat itu sendiri. Komunitas sebagai pemilik budaya memiliki peran untuk melestarikannya. Pertunjukan seni memiliki bentuk yang berbeda satu sama lain. Pertunjukan seni itu sendiri memiliki arti khusus dan ini sesuai dengan konteksnya. Pertunjukan musik Nggo Lamba di Lio Ende Flores Nusa Tenggara Timur adalah seni pertunjukan rakyat yang digunakan untuk menemani tarian adat di berbagai jenis upacara adat seperti upacara syukuran, upacara pernikahan, upacara Pati Ka dan lain-lain. Tulisan ini merupakan deskripsi dari proses seri sebuah Upacara Pati Ka di danau Kelimutu mulai persiapan hingga puncak acara.
\end{abstract}

Kata kunci: Nggo Lamba, Pati Ka Du'a Bapu Ata Mata.

\footnotetext{
${ }^{1}$ Mahasiswa jurusan Etnomusikologi FSP ISI Yogyakarta.
} 


\section{Pendahuluan}

Nggo Lamba merupakan salah satu ansambel musik etnis yang berasal dari Ende Lio. Ende merupakan salah satu Kabupaten yang terletak di tengah Pulau Flores, dan salah satu suku yang mendiami daerah tersebut adalah suku Lio.Masyarakat setempat hingga saat inimasih memiliki sistem kepercayaan turun temurun yang diwarisi dari para leluhur.Salah satu yang diwarisi tersebut adalah Nggo Lamba.Nggo Lamba merupakan salah satu kesenian yang cukup terkenal di daerah Ende Lio,karena sering digunakan dalam setiap acara-acara penting.

Keberadaan ansambel musik Nggo Lamba yang diulang-ulang,gembira dan bersemangat merupakan beberapa ciri khas saat melihat pertunjukan musik tersebut.Awal menyaksikan pertunjukan ini terlintas bahwa musik ini adalah musik kuno yang hanya berada di lingkup masyarakat desa daerah Ende Lio, sebab musik ini memiliki ciri khas yang tidak terdapat dimasyarakat lainnya di pulau Flores.

Ansambel musik Nggo Lambadijumpai di berbagai daerahLio. Instrumen tersebut sampai saat ini masih dipertahankan sebagai musik pengiring tarian, dan juga sebagai musik tradisional pengiring saat syukuran, saat pesta adat, saat pembuatan atap rumah adat, dan disaat kematian Mosalaki (kepala suku). Musik Nggo Lamba lebih sering dipertunjukan pada saat pesta adat, salah satunya pada saat upacarapernikahan.Ansambel ini dijadikan sebagai pengiring arak-arakan yang mengantarkan pengantin dan keluarga ke tempat upacara pemberkatan nikah.Nggo Lamba juga digunakan dalam sebuah aktivitas budaya masyarakat Ende Lio yang berhubungan dengan kepercayaan nenek moyang yaitu memberi makan arwah leluhur yang disebut dengan Pati Ka Du'a Bapu Ata Mata.

Pati $\mathrm{Ka}$ dalam tradisi Ende Lio merupakan upacara ritual menyajikan makanan khusus sebelum panen padi ladang. Ritual Pati Ka Du'a Bapu Ata Mata sudah berlangsung sejak dahulu dilakukan di setiap kampung adat di wilayah Lio dan menurut kepercayaan masyarakat Lio bahwa ritual ini dilakukan untuk berkomunikasi dan memelihara relasi dengan para leluhur dan alam semesta. Pati Ka Du'a Bapu Ata Mata merupakan ritual untuk penghormatan dengan memberi makan atau sesaji kepada leluhur yang dilakukan di puncak danau Kelimutu. 
Terbentuknya acara ini telah disepakati bersama antara pemerintah daerah Ende bekerja sama dengan Kementrian Kebudayaan dan Pariwisata sejak 5 tahun terakhir.

Kesepakatan itu juga menyentuh tata cara pelaksanaan ritual secara bersama karena tata cara ritual ini melibatkan dua puluh komunitas yang berada di sekitar wilayah penyangga gunung Kelimutu dan memililiki ritual serupa di wilayahnya masing-masing.

Musik Nggo Lamba dimainkan dalam setiap upacara adat dengan mengenakan pakaian adat yaitu luka (selendang adat Lio), lesu (ikat kepala), dan ragi (kain adat Lio untuk laki-laki), kadang juga mengenakan baju putih polos lengan panjang dan para wanita mengenakan lawo (kain sarung untuk perempuan) dan lambu (baju adat Lio untuk perempuan).Instrumen yang digunakanseperti Nggo atau biasa disebut gong.Nggo yang digunakan terdiri dariDhou 1 buah, Dhiri 1 buahdan Lamba/Tambur 2 buah.

Setelah diamati lebih mendalam, ternyata ansambel musik Nggo Lamba merupakan salah satu musikkhas tradisional yang ada di Ende Lio.Suatu kebudayaan dari daerah setempat berkaitan erat dengan agama dan kepercayaan masyarakatnya (Brata, 2007: 25).Inilah yang terjadi pada Nggo Lamba di Ende Lio, awalnya masyarakat menganggap ansambel ini hanya sebagai ansambel musik pengiring atau musik arak-arakan saja, namun sebenarnya dari semua itu terdapat kepercayaan-kepercayaan masyarakat setempat akan ansambel musik tersebut. Kepercayaan itulah yang membuat ansambel Nggo Lamba ini dari dulu hingga sekarang tidak banyak mengalami perkembangan dalam instrumennya, dan ansambel musik ini tidak diketahui secara pasti sejak kapan muncul dan berkembang di daerah tersebut.

Kesenian tidak pernah berdiri lepas dari masyarakat. Sebagai salah satu bagian yang penting dari kebudayaan, kesenian merupakan ungkapan kreativitas dari kebudayaan itu sendiri. Sesuatu yang disebut "seni rakyat", "lagu rakyat", atau "tarian rakyat"yang tidak pernah dikenal lagi penciptanya itu pada mulanya dimulai dari seorang pencipta anggota masyarakat (Kayam, 1981: 39).Hal ini yang terjadi pada musik Nggo Lamba di Ende Lio Flores NTT.Musik yang sudah 
tidak memiliki penciptanyalagi dan sampai saat ini tidak ada pula yang mengembangkan pola permainannya, namun hingga saat ini ansambel musik Nggo Lamba masih selalu dipakai dalam arak-arakan upacararitual pengantin dan upacara ritual adat lainnya.Banyak musik ritual disana tetapi hanya Nggo Lamba yang selalu dijadikan musik ritual nomor satu atau paling sering digunakan di Ende Lio.Ansambel musik ini digunakan karena dianggap paling sakral danberkaitan dengan Sang Pencipta. Namun hingga saat ini ansambel Nggo Lamba khususnya masih dipakai dalam upacara adat dan seniman masyarakatmulai mengangkatnya kembali di dalam buku kumpulan musik-musik Lio.Ansambel ini digunakan karena dianggap sakral, baik dari segi instrumennya maupun dari segi upacara adatnya.

Keberadaan ansambel musik Nggo Lambatersebut, sampai saat ini masih dianggap tetap sama seperti dahulu atau tidak pernah dilakukan perkembanganperkembangan baik dari segi instrumen, teknik permainan dan para pemainnya.Ansambel musik ini haruslah tetap seperti apa adanya dan tidak boleh dikembangkan dalam bentuk apapun. Meskipun demikian, musik ini tetap bertahan pada masyarakat Lio di kabupaten Ende (Ndopo, 2015).

Apabila ansambel musik Nggo Lambadibunyikan maka semua masyarakat dalam daerah tersebut harus berhenti beraktivitas dan masyarakat setempat mengatakan bahwa ansambel musik ini tidak dapat dikembangkan. Hal ini menjadi sebuah kajian menarik untuk dibahas.Musik tradisional padaumumnya,mendapat perkembangandari masyarakatnya.Akan tetapi, hal yang terjadi pada ansambel musik Nggo Lamba tidak diperbolehkan untuk dikembangkan, karena nantinyamembuat kesenian tersebut menjadi kehilangan penerus yang akan mewarisinya.

\section{Ansambel Musik Nggo Lamba}

Ansambel musik Nggo Lamba juga dimainkan dalam acara sepekan pesta danau Kelimutu. Acara tersebut merupakan acara yang diselenggarakan oleh pemerintah bekerja sama dengan dinas Kebudayaan dan Pariwisata kabupaten 
Ende. Sepekan pesta danau Kelimutu telah dijadikan acara tahunan sejak 5 tahun terakhir. Sepekan Pesta Danau Kelimutu diawali dengan beberapa prosesi adat di antaranya, pada hari Rabu 10 Agustus 2016 dilaksanakan upacara weza kamba/ wela kambaartinya menyembelih kerbau yang dilakukan secara simbolis oleh pemerintah dan seluruh Mosalaki kabupatenEndedi Museum Tenun Ikat. Upacara wela kamba diawali dengan prosesi etnis Ende dan etnis Lio diikuti oleh seluruh tokoh adat dan mosalaki, tokoh pemerintah dan tokoh agama, yang berangkat dari arah timur Jalan Soekarno sampai ke Museum Tenun Ikat, diiringi dengan tarian wanda pa'u. Selanjutnya dilakukan upacara wela kamba yang dilakukan oleh Bupati dan Wakil Bupati disaksikan oleh seluruh mosalaki (kepala suku) dan tokoh agama.

Pada hari berikutnya Kamis 11 Agustus 2016 dilaksanakan rapat koordinasi Tiga Batu Tungku, yang pada umumnya semboyan tersebut merupakan berbagai elemen masyarakat yang memiliki peranan penting dan merupakan kekuatan utama dalam pembangunan daerah. Elemen masyarakat yang dimaksud tersebut adalah tokoh pemerintah, tokoh agama dan tokoh adat. Para tokoh agama dan para mosalaki dibagi dalam beberapa kelompok untuk berdiskusi, hal yang didiskusikan merupakan kegiatan pembangunan kabupaten Ende. Rapat tersebut dilaksanakan agar tokoh agama, pemerintah dan tokoh adat dapat saling bertukar pikiran dan memberi solusi serta memberi motivasi bagi masyarakat untuk ikut menggerakkan pembangunan wilayah kabupaten Ende agar lebih baik ke depannya.

Sepekan pesta danau Kelimutu tahun 2016 dimeriahkan dengan pagelaran seni budaya dan pameran produk lokal berupa makanan khas Ende Lio, kain tenun dan pernak-pernik khas Ende Lio.

Pergelaran seni budaya yang dipertunjukan berupa lomba tarianadat yang hanya diikutioleh 5 kecamatan yaitu, kecamatan Ende Tengahyang menampilkan sendratari Ia, Meja, Wongge yang menceritakan legenda gunung Ia, Meja dan Wongge. Kecamatan Wolojita menampilkan sendratari dengan judul Manu Jata Ria Rembe $($ Manu = ayam, Jata = burung rajawali, dan Ria Rembe = kekerasan yang dilakukan oleh orang dewasa). Kecamatan Ende menampilkan tarian Dowe 
Nggo merupakan tarian pemujaan terhadap dewi padi, tarian ini biasa dilakukan oleh para leluhur Ende pada saat menanam padi dan jagung. Kecamatan Ende Timur menampilkan tarian Ine Pare (Dewi Padi). Kecamatan Ende Utara menampilkan tarian Po'o Ae (bambu tempat tampung air).

Pada hari Jumat 12 Agustus 2016 diadakan Parade Carnaval Budaya Nusantara. Carnaval Budaya ini diikuti oleh seluruh sekolah dan komunitas sanggar budaya yang ada di kabupaten Ende. Materi yang dicarnavalkan adalah pakaian adat dari seluruh nusantara. Rute carnaval dimulai dari halaman kantor Bupati - Jalan Eltari - Jalan Kelimutu - Jalan Banteng - Jalan Sudirman dan berakhir di lapangan Pancasila di Jalan Soekarno.Setibanya di Lapangan Pancasila, acara dilanjutkan dengan atraksi drumband dari beberapa sekolah yaitu Pondok Pesantren Walisanga Ende, SMPK Maria Goretti Ende, SMPK Frateran Ndao Ende. Atraksi terakhir adalah Reog Ponorogo yang ditampilkan oleh Sanggar Reog Ponorogo asal Surabaya.

Hari berikutnya Sabtu tanggal 13 Agustus 2016 diadakan lomba trekkingdi kawasan taman nasional Kelimutu. Lomba trekking diikuti oleh seluruh peserta dari Pemerintah pusat dan Pemerintah kabupaten Ende. Acara puncak pada Minggu 14 Agustus 2016 merupakan acara Pati Ka Du'a Bapu Ata Mata. Acara di puncak Kelimutu ini diselenggarakan oleh Taman Nasional Kelimutu bekerja sama dengan Dinas Kebudayaan dan Pariwisata Kabupaten Ende serta melibatkan 20 komunitas adat yang mendiami wilayah sekitar Taman Nasional Kelimutu yang secara tradisi memiliki ikatan religi dengan danau Kelimutu sebagai tempat arwah leluhur.Pati Ka Du'a Bapu Ata Matadimulaidengan prosesi para pelaku ritual yang didominasi oleh perwakilan dari komunitas adat dan peserta lainnya baik dari kalangan Pemerintah, Taman Nasional Kelimutu serta para pengunjung Kelimutu yang terdiri dari wisatawan asing, wisatawan domestik serta pengunjung lokal. Acara dimulai dengan penyambutan Bupati dan wakil Bupati serta para komunitas adat kawasan taman nasional Kelimutu. Penyambutan diiringi dengan musik Nggo Lamba serta tarian adat, yang bertempat di lapangan parkir Taman Nasional Kelimutu. Semua persiapan untuk ritual Pati Ka Du'a Bapu Ata Mata di puncak Kelimutu dipusatkan di sebuah Kuwu (tempat musyawarah tetua adat). 
Sebanyak 20 komunitas adat penyangga kawasan Taman Nasional Kelimutu ikut serta dalam ritual Pati Ka Dua Bapu Ata Mata.

makanan dan minuman yang akan dipersembahkan untuk para leluhur pun disiapkan di antaranya nasi merah, daging babi, sirih pinang, tembakau dan moke (arak khas Lio). Semua makanan tersebut merupakan makanan adat khusus bagi masyarakat Ende Lio yang wajib disajikan dan ditata di tempat khusus yaitu pane (tempat makanan khas Ende Lio yang terbuat dari tanah). Prosesi dimulai pada pukul 11:30 WITA, dan dari Kuwu ke lokasi Pati Ka dilakukan dengan berjalan kaki sejauh kira-kira $1 \mathrm{~km}$ ke arah puncak Kelimutu. Semua pembawa sesaji dan masyarakat yang berjalan menuju lokasi diam tidak bersuara, kecuali bunyi gong. Para pemimpin komunitas adat atau Mosalaki Pu'u melaksanakan puncak ritual Pati $\mathrm{Ka}$ yaitu diawali dengan memberikan makan kepada leluhur, dan semua Mosalaki berdiri mengelilingi mesbah tempat sesaji.

Pemberian sesajian itu diikuti dengan pengucapan kata-kata religius sebagai berikut.

Du'a bapu ata mata (nenek moyang dan para leluhur)

Leja ina kami mai tii tu (hari ini kami datang membawa)

Ola kema mbale ola (hasil kerja kami di atas pelataran agung)

bugu gha kanga pu'u kelimutu (Kelimutu)

Ngodho molo simo pawe (terimalah semuanya ini dengan baik)

Kami iwa se'u (kami tidak ingin merebut)

Kami iwa sengge (kami tidak ingin menguasai)

Kami mangga fe naja (kami hanya memanggil namamu seperti)

dede ngere lele (desiran pohon beringin)

Wake naja ame ngere mase (mengagungkan namamu seperti batu perkasa)

Tau mbeo sawe mena du (semua yang dari timur dan barat tahu)

Miu ata jaga mutu masa (kamu yang menjaga Kelimutu)

Jaga mara mamo ana (lindungilah anak cucu)

We Ende Lio sare pawe (agar Ende Lio baik dan sejahtera).

Lalu mereka meletakan sesajian tersebut di atas mesbah. Para Mosalaki yang dipercayakan membawa sajian duduk di sekitar altar tempat persembahan. Selesai memberi makan, makanan itu dibagikan sedikit-sedikit di antara mereka. Mereka makan bersama sambil meminum moke dan mengisap tembakau. Ritual tersebut diakhiri dengan tarian Gawi Sodha oleh para Mosalaki Pu'u mengelilingi 
altar sesajian.Semua sesaji dalam upacara Pati $K a$ memiliki makna sebagai berikut.

\section{Nasi Merah atau Beras Merah}

Nasi merah atau berah merah adalah hasil pertanian dan bahan makanan pokok orang Ende Lio. Beras dalam sesaji ini dapat diartikan sebagai bekal bila bepergian bahkan sebagai simbol pertanian, simbol kesuburan dan mewakili mata pencaharian yang sudah dirawat mulai dari menanam, memberikan pupuk, dan saat panen tiba padi dipetik dan digiling sehingga menjadi beras yang akan diolah menjadi nasi. Beras merah atau nasi merah bukan sesuatu yang didapatkan dengan mudah, maka dari itu beras merah bukanlah sesaji sembarangan yang disajikan dalam upacara Pati Ka. Bagi masyarakat Ende Lio, menyajikan nasi merah atau nasi putih dalam upacara Pati Ka sebenarnya sama saja. Makna nasi merah tidak jauh berbeda dengan nasi putih yakni sebagai makanan pokok.

\section{Daging Babi}

Daging babi merupakan hasil peternakan yang banyak dipelihara oleh masyarakat Ende Lio dan dipelihara dalam waktu yang lama, mulai dari memberinya makan agar tumbuh dengan baik, merawatnya agar tidak terkena penyakit sehingga pada saatnya diperlukan akan menghasilkan daging yang segar dan sehat. Daging babi juga disajikan dalam upacara Pati $K a$, hal ini dikarenakan menurut tradisi dalam setiap upacara adat di Ende Lio, makanan lain yang wajib disajikan yakni daging babi, sehingga dapat dikatakan bahwa daging babimerupakan salah satu makanan adat yang disukai, mewah dan terhormat bagi masyarakat Ende Lio sejak dulu sampai sekarang.

\section{Pane (tempat sesaji)}

Menurut tradisi Ende Lio, dalam menyajikan makanan khusus untuk acaraacara ritual adat seperti upacara Pati $\mathrm{Ka}$ ini harus menggunakan pane. Pane adalah tempat untuk meletakkan sesaji yang terbuat dari bahan alami yakni tempurung kelapa, dan ada juga yang terbuat dari bahan olahan teknologi seperti tanah liat. Hal ini dikarenakan pane tersebut merupakan warisan orang tua sejak 
dahulu dan akan berkelanjutan sampai masa yang akan datang, sehingga jika menyajikan makanan dalam upacara ritual adat apapun di Ende Lio harus ditempatkan pada pane.

\section{Tembakau}

Suguhan selingan dalam aktivitas makan dalam kehidupan masyarakat Ende Lio merupakan hal yang sangat penting. Salah satu suguhan/ sajian selingan dalam upacara Pati Ka Du'a Bapu Ata Mata adalah tembakau. Tembakau yang disajikan berupa tembakau paga yang merupakan tembakau khas dari daerah Ende Lio. Tembakau ini ditanam sendiri oleh masyarakat adat yang ada di kabupaten Ende, sehingga tidak dapat didatangkan dari luar. Kuping atau pembungkus tembakau menggunakan kulit jagung. Hal ini sama dengan tembakau, kuping ini berasal dari masyarakat adat yang ada di kabupaten Ende, umumnya masyarakat Lio. Tembakau memiliki makna secara khusus yaitu sebagai simbol pergaulan dan keakraban bagi orang tua laki-laki.

\section{Sirih Pinang}

Sama halnya dengan tembakau, sirih pinang juga merupakan makanan selingan yang disajikan dalam upacara Pati Ka Du'a Bapu Ata Mata. Ciri khas adat yang berlaku di kabupaten Ende adalah sirih, dan sirih pinang memiliki perlambang khusus yaitu sebagai simbol kecantikan bagi orang tua perempuan. Hal ini dikarenakan sirih jika dimakan akan menjadi warna merah dan orang tua dulu untuk menghias bibir baik wanita maupun pria harus menggunakan sirih. Sama halnya sekarang perkembangan zaman terutama bagi kaum muda, menghias bibir dengan menggunakan yang namanya lipstik

\section{Moke (tuak)}

Moke merupakan minuman adat khas Ende Lio yang terbuat dari bahan alami yaitu dari pohon lontar atau enau. Moke merupakan simbol kegembiraan atau kebebasan. Pesta adat, upacara ritual, acara pernikahan dan acara adat lainnya selalu disajikan moke. Hal ini sudah dilakukan sejak dahulu hingga sekarang. 
Moke biasa diletakkan di sebuah ceret/ kendi yang terbuat dari tanah liat dan dituangkan di cangkir yang terbuat dari tanah liat pula, lalu disuguhkan bagi yang membutuhkan.

Bentuk mengandung pengertian sebagai hasil pernyataan dari berbagai macam unsur yang didapatkan secara kolektif melalui vitalitas estetik atau dapat pula diartikan aspek secara estetik merupakan penilaian dari pihak lain sebagai pengamat (Smith, 1985: 6). Ansambel musik Nggo Lambamemiliki bentukberupa wujud yang dapat diamati meliputimacam-macam instrumen yang digunakan dan pola permainan. Bentuk penyajian dalam salah satu jenis seni pertunjukan merupakan dua hal yang saling berhubungan yang saling mendukung satu sama lainnya. Bentuk penyajian musik Nggo Lamba yang berkaitan dengan seni pertunjukan merupakan suatu sistem atau cara penyajian secara keseluruhan dari pertunjukan ansambel musik tersebut.

Ansambel musik merupakan kelompok kegiatan musik yang memainkan musik secara bersama-sama, dengan menggunakan beberapa alat musik tertentu, baik secara melodis, ritmis maupun harmonis. Musik merupakan salah satu sarana ritual yang digunakan sebagai sarana upacara sejak zaman dahulu. Musik yang digunakan dalam upacara disebut dengan musik ritual, baik upacara keagamaan, upacara tradisional dan upacara kenegaraan. Musik yang digunakan dalam upacara tradisional erat kaitannya dengan unsur kepercayaan kepada roh para leluhur. Sama seperti musik ritual yang ada pada masyarakat Ende Lio yaitu musik Nggo Lamba yang digunakan pada acara ritual adat. Penyajian musik ritual kebudayaan selalu berkedudukan sebagai bagian dari upacara, pengiring dan pendukung upacara (Soedarsono, 1998: 60). Ciri seni ritual juga disampaikan bahwa tempat pertunjukan atau penyajian musik ritual, pemain harus laki-laki, merupakan aspek-aspek yang tentunya menjadi unsur yang harus dipenuhi. Konsep-konsep tersebut di atas jika dilihat dengan seksama dapat dikemukakan bahwa keritualan bentuk penyajian musik tersebut tampak pada instrumen, tempat, waktu, dan peruntukkan musik tersebut disajikan. Aspek-aspek ritual tersebut terbagi dalam dua aspek yaitu aspek non musikal dan aspek musikal. Ansambel Nggo Lamba memilik aspek non musikal yang terdiri dari tempat 
penyajian, waktu penyajian dan pelaku pertunjukan sedangkan aspek musikal terdiri dari instrumen, pola permainan dan transkripsi.

Penyajian musikal dalam ansambel Nggo Lambamenyangkut semua aspek bunyi (audio) yang dihasilkan dari aktivitas bermusik. Bunyi yang dihasilkan dari ansambel Nggo Lamba merupakan bunyi-bunyian ritual yaitu bunyi-bunyian yang disajikan dalam rangkaian upacara, baik dalam upacara agama maupun upacara budaya yang meliputi upacara adat dan upacara kenegaraan. Selain itu, bunyibunyian ritual disajikan sesuai dengan tempat yang disakralkan (Senen, 2015: 97). Ansambel musik Nggo Lamba merupakan musik yang dimainkan dalam setiap upacara adat dan dimainkan di tempat yang disakralkan salah satunya puncak danau Kelimutu, oleh karena itu bunyi-bunyian yang dihasilkan dari ansambel tersebut dikategorikan sebagai bunyi-bunyian ritual.

Musik rakyat pada umumnya bersifat monoton yang berarti cenderung berulang-ulang, khususnya pada ansambel Nggo Lamba yang merupakan musik tradisional khas Ende Lio. Setiap instrumen memiliki pola yang monoton namun dengan tempo yang disesuaikan dengan ritme permainan Nggo dan Lamba. Pola dari beberapa instrumen dalam ansambel Nggo Lamba sebagai berikut.

\section{1) $\mathrm{Nggo} 1$}

Nggo 1 terdiri dari tiga buah Nggo (gong) dengan nada F, A\#, B. Nada yang disebutkan tersebut merupakan nada berdasarkan instrumen Nggo Lamba yang dimainkan di lapangan parkir Taman Nasional Kelimutu tanggal 14 Agustus 2016 dan instrumen tersebut milik desa Wologai Tengah. Nggo 1 merupakan leader (pemimpin) dalam perpindahan pola permainan. Ketika Nggo 1 mengubah pola permainan maka Nggo 2 akan mengikutinya pula. Nggo 1 lebih variatif daripada Nggo 2 dalam mengembangkan bunyi. Pola permainan Nggo 1 sebagai berikut.

Nggo 1 


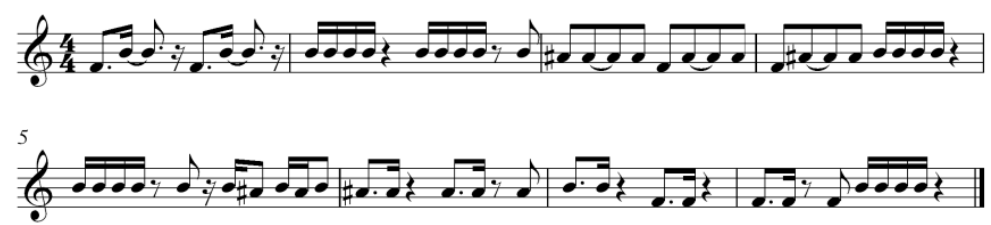

2) $\mathrm{Nggo} 2$

Nggo 2 merupakan pengiring dalam pola permainan nada ansambel musik Nggo Lamba dan cenderung bermain dengan konstan dan teratur. Nggo 2 terdiri dari 2 instrumen yaitu nada D dan G. Pola isian nada Nggo 2 terdengar lebih sederhana contohnya memakai nada $1 / 4$ dan biasanya bermain pada jatuhnya ketukan bawah (down). Ketika Nggo 1 merubah pola permainannya maka Nggo 2 biasanya mengikuti. Pola permainan Nggo 2 sebagai berikut.

Nggo 2

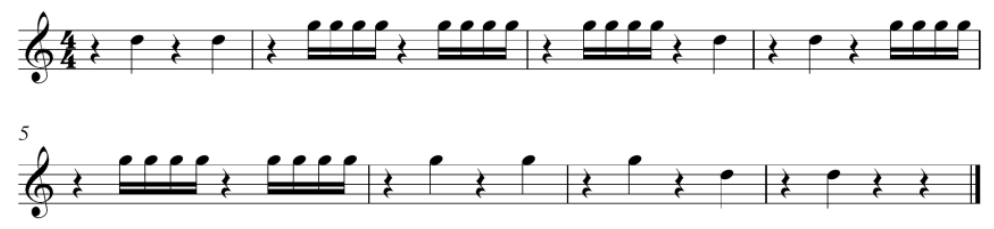

\section{3) $L a m b a$}

Lamba memainkan pola perkusi yang sama secara terus-menerus atau konstan dan pola permainanya monoton. Perubahan tema terjadi ketika pola permainan tersebut dirasa sudah cukup. Permainan Lamba merupakan permainan yang memberi kesan arak-arakan. Pola permainan Lamba sebagai berikut. lamba 


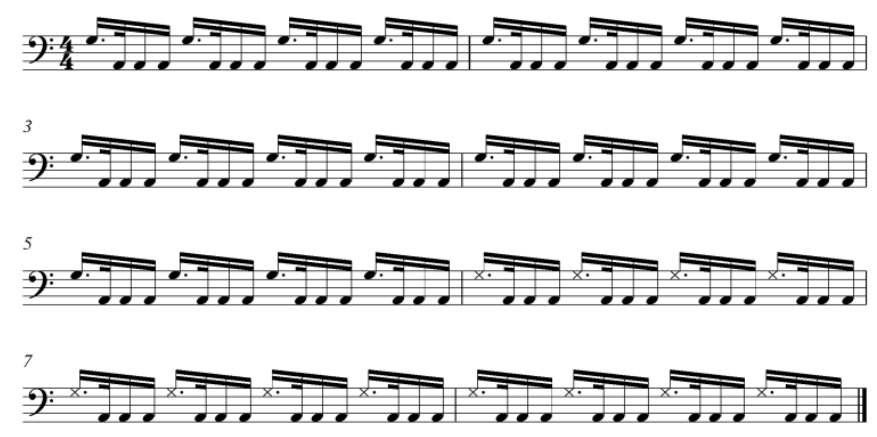

4) Ceng

Pola permainan Ceng monoton dan merupakan pemegang tempo dalam iringan musik Nggo Lamba. Permainan Ceng sama dengan permainan Lamba yang memberi kesan arak-arakan. Pola permainan Ceng sebagai berikut.

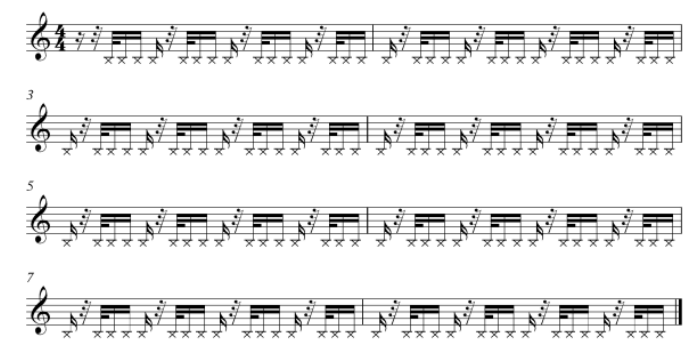

\section{Kesimpulan}

Bentuk penyajian musik Nggo Lamba dibedakan menjadi dua aspek yaitu aspek non musikal dan aspek musikal. Aspek musikal merupakan bentuk penyajian yang berhubungan dengan suara (audio). Aspek musikal tentunya berkaitan dengan instrumen dan musiknya. Ansambel Nggo Lamba merupakan bentuk musik instrumental dan dimainkan berulang-ulang. Nada yang digunakan pada instrumen Nggo 1 adalah nada F, A\#, B, Nggo 2 adalah nada D, dan G. Nada-nada tersebut disesuaikan dengan instrumen Nggo yang dimainkan oleh komunitas desa Wologai Tengah dalam upacara Pati Ka Du'a Bapu Ata Mata di danau Kelimutu, sehingga dapat dikatakan bahwa nada dalam setiap ansambel musik Nggo Lamba dari setiap daerah di Ende Lio itu berbeda-beda.

Aspek non musikal merupakan bentuk penyajian yang berkaitan dengan visual atau sesuatu yang nampak. Aspek non musikal terdiri dari waktu 
pertunjukan, tempat pertunjukan dan pelaku pertunjukan. Ansambel musik Nggo Lamba merupakan musik ritual yang diwariskan oleh para leluhur sejak dulu dan musik ini merupakan musik khas tradisional Ende Lio yang memiliki peranan penting dalam berbagai acara adat sehingga pola permainannya tidak dapat dikembangkan. Hal ini dikarenakan dalam tradisi masyarakat Ende Lio percaya jika musik Nggo Lamba sudah dibunyikan maka semua aktivitas di daerah setempat harus dihentikan, seperti apapun bentuk segala aktivitasnya. Sama halnya dalam upacara Pati Ka Du'a Bapu Ata Mata, ketika Nggo dibunyikan semua masyarakat yang mengikuti prosesi upacara tersebut, juga diharuskan untuk hening, sehingga prosesi itu berjalan dengan hikmat sesuai dengan tata cara adat Lio.

Ansambel musik Nggo Lamba yang digunakan pada upacara ritual tersebut perludilestarikan, karena ini juga merupakan salah satu kekayaan dari kebudayaan Indonesia yang patut dipertahankan sebagai kebanggaan yang dapat membentuk atau membangun karakter bangsa.

\section{Daftar Pustaka}

Brata, Nugroho Trisnu. 2007. Antropologi. Jakarta: Erlangga.

Dinas Kebudayaan dan Pariwisata. 2013. Profil Pariwisata Kabupaten Ende. Ende: Dinas Pariwisata.

Hendarto, Sri. 2011. Organologi dan Akustika I\&II. Bandung: CV. Lubuk Agung.

Kayam, Umar. 1981. Seni, Tradisi, Masyarakat. Jakarta: Sinar Harapan.

Kusmayati, A. M. Hermien. 2000. Arak-Arakan Seni Pertunjukan dalam Upacara Tradisional di Madura. Yogyakarta: Yayasan untuk Indonesia.

Meko Aron, Deidhae Ferry, Bhanda, Maria Matildis, Wake Petrus. 2004. Khazanah Budaya Lokal di Kabupaten Ende. Ende: Dinas Pendidikan dan Kebudayaan.

Nettl, Bruno.1964. Theory and Methods in Etnomusicology. London: The Free Press of Glencoe Collier-Macmillan Limited. 
Senen, I Wayan. 2015. Bunyi-bunyian Dalam Upacara Keagamaan Hindu Di Bali. Yogyakarta: Institut Seni Indonesia.

Smith, Jacqueline.1985. Komposisi Tari Sebuah Petunjuk Praktis bagi Guru" terj. Ben Suharto. Yogyakarta: IKAPI.

Soedarsono, R.M. 1998. Seni Pertunjukan Indonesia Di Era Globalisasi. Jakarta: Direktorat Jendral Pendidikan Tinggi, Departemen Pendidikan dan Kebudayaan.

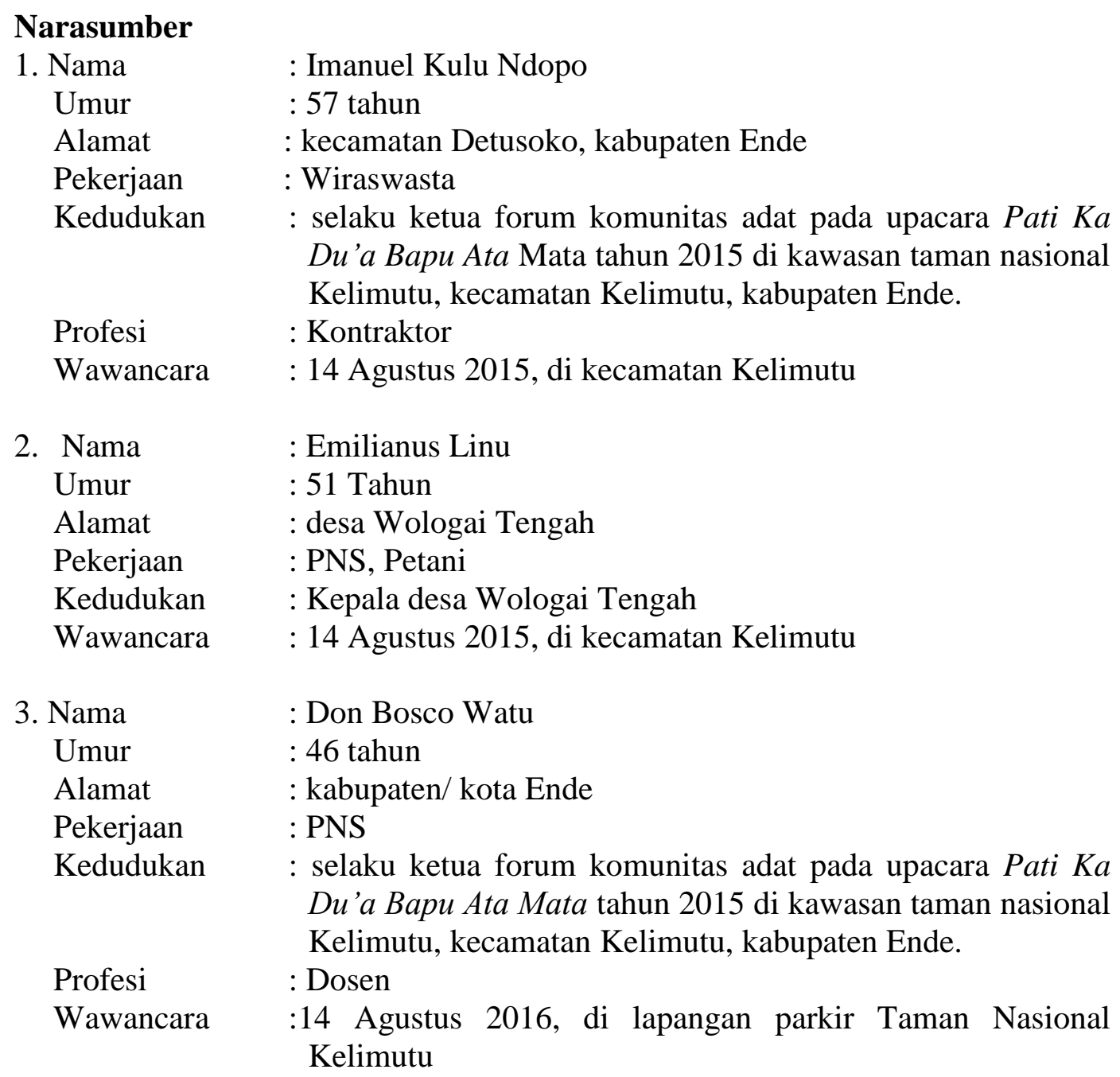

